\title{
Comparative Evaluation of the Amino Acid Profile of the Brain and Eyes of Guinea Fowl (Numida meleagris) Hen
}

\author{
Emmanuel Ilesanmi Adeyeye ${ }^{\mathrm{a}, *}$ and Matthew Olalekan Aremu ${ }^{\mathrm{b}}$ \\ ${ }^{a}$ Department of Chemistry, University of Ado-Ekiti, PMB 5363, Ado-Ekiti, Nigeria \\ ${ }^{b}$ Department of Chemistry, Nasarawa State University, PMB 1022, Keffi, Nigeria
}

\begin{abstract}
The amino acid composition of the brain and eyes of the matured female guinea fowl (Numida meleagris) was determined on a dry weight basis. The total essential amino acids ranged from 38.4-37.5g/100 g crude protein or from 47.5-52.2\% of the total amino acid. The amino acid score showed that lysine ranged from $0.81-0.89$ (on whole hen's egg comparison), 0.92-1.00 (on provisional essential amino acid scoring pattern) and $0.869-0.95$ (on suggested requirement of the essential amino acid of a preschool child). The predicted protein efficiency ratio was $1.82-2.33$, the essential amino acid index range was $1.11-1.45$ and the calculated isoelectric point range was $4.64-4.32$. The correlation coefficient $\left(r_{x y}\right)$ was positive and significant at $r_{0.05}$ for the total amino acids, amino acid scores (on all the comparisons made) and the isoelectric point in the two samples. Results have good comparison with whole hen's egg protein.
\end{abstract}

Keywords: Amino acid profile, brain, eyes, guinea fowl hen.

\section{INTRODUCTION}

The guinea fowl (Numida meleagris) thrives under semi-intensive conditions, forages well and requires little attention. It retains many of its wild ancestor's survival characteristics: it grows, reproduces, and yields well in both cool and hot conditions; it is relatively disease free; it requires little water; it is almost as easily raised as chickens and turkeys; and it is a most useful all-round farm bird [1].

Meat from domestic guinea fowl is dark and delicate, the flavour resembling that of game birds. It is a special delicacy, served in some of world's finest restaurants. Several European countries eat vast amounts. Annual consumption in France, for example is about $0.8 \mathrm{~kg}$ per capita [1].

Guinea fowl also produces substantial numbers of eggs. In Africa, these are often sold hard-boiled in local markets. In the Soviet Union, they are produced in large commercial operations. In France, guinea fowl strains have been developed that not only grow quickly but lay as many as $190 \mathrm{eggs}$ a year.

Guinea fowl production is beginning to increase all over the world. There are no reports on the chemical composition of female guinea fowl meat. Due to the emphasis placed on the nutritive value of food by consumers a great need exists for information on nutritional composition of guinea fowl meat. In this part of the world the head of guinea fowl is usually reserved and given to the preschool child $(2-5$ years old) for consumption after cooking. The present study was therefore undertaken in attempt to gain some information

*Address correspondence to this author Department of Chemistry, University of Ado-Ekiti, PMB 5363, Ado-Ekiti, Nigeria; Tel: +238035782925;

E-mail: eiadeyeye@yahoo.com on the amino acid of the head organs (brain and eyes) of the guinea hen. The guinea fowl sample used was the pearl type.

\section{MATERIALS AND METHODS}

\section{Preparation of Samples}

The guinea fowl hen used was a matured bird. Prior to butchering, food was withheld for a day to help ensure the digestive system was empty. Head was held on the stump and the guinea head removed with an axe. At the end of bleeding, the guinea was plucked. When all the feathers had been removed, the head was rinsed and dried in the oven. After drying, the eyes and brain were separately extracted, ground, sieved and kept in freezer in McCartney bottles pending analysis. Five birds (all free range) were used in the study. Their ages varied between $42-45$ weeks with a weight range of $1.2-1.5 \mathrm{~kg}$.

\section{Crude Protein Determination and Fat Extraction}

The micro-Kjeldahl method as described by Pearson [2] was followed to determine the fat-free crude protein. The fat was extracted with a chloroform/methanol $(2: 1 \mathrm{v} / \mathrm{v})$ mixture using Soxhlet extraction apparatus [3].

\section{Amino Acid Analysis}

Between 30mg and 35mg defatted samples were weighed into glass ampoule, $7 \mathrm{ml}$ of $6 \mathrm{M} \mathrm{HCl}$ added and hydrolyzed in an oven preset at $105 \pm 5^{\circ} \mathrm{C}$ for $22 \mathrm{~h}$. Oxygen was expelled in the ampoule by passing nitrogen gas into it. Amino acid analysis was done by ion-exchange chromatography [4] using a Technicon Sequential Multisample Amino Acid Analyzer (Technicon Instruments Corporation, New York, USA). The period of analysis was $76 \mathrm{~min}$, with a gas flow 
rate of $0.50 \mathrm{ml} / \mathrm{min}$ at $60^{\circ} \mathrm{C}$, and the reproducibility was \pm $3 \%$. Tryptophan was not determined.

\section{Estimation of Isoelectric Point (pI)}

The theoretical estimation of isoelectric point (pI) was determined using the equation of Olaofe and Akintayo [5] and information provided by Finar [6]:

$I P m=\sum_{i=1}^{n} I P_{i} X_{i}$

Where IPm $=$ the isoelectric point of the $i^{\text {th }}$ amino acid in the mixture;

$X_{i}=$ the mass or mole fraction of the $i^{\text {th }}$ amino acid in the mixture.

\section{Estimation of Predicted Protein Efficiency Ratio (P- PER)}

The predicted protein efficiency ratio (P-PER) was estimated by using the equation of the form [7]:

$\mathrm{P}-\mathrm{PER}=-0.468+0.454$ (Leu) -0.105 (Tyr)

\section{Estimation of Dietary Protein Quality}

The amino acid scores were calculated using three different procedures:

(i) Scores based on amino acid values compared with whole hen's egg amino acid profile [8];

(ii) Scores based on essential amino acid scoring pattern [9];

(iii) Scores based on essential amino acid suggested pattern of requirements for preschool child [10].

\section{Estimation of Essential Amino Acid Index (EAAI)}

The essential amino acid index (EAAI) was determined using the method of Steinke et al. [11].

\section{Leucine/Isoleucine Ratio}

The leucine/isoleucine ratios, their differences and their percentage differences were also calculated.

\section{Statistical Analysis}

The statistical analysis carried out included the determination of the grand mean, standard deviation (SD) and the coefficients of variation percent $(\mathrm{CV} \%)$. Other calculations made were the simple linear correlation coefficient $\left(\mathrm{r}_{\mathrm{xy}}\right)$, coefficient of determination $\left(\mathrm{r}_{\mathrm{xy}}{ }^{2}\right)$, coefficient of alienation (or index of lack of relationship) $\left(\mathrm{C}_{\mathrm{A}}\right)$ and index of forecasting efficiency (IFE) and subjected to table standards to test for significance difference, the level of probability was set at $\mathrm{r}_{0.05}$ at $\mathrm{n}-2$ degrees of freedom [12].

\section{RESULTS AND DISCUSSION}

Table 1 presents the amino acid composition of the samples. Glu and Asp were the most concentrated amino acid (AA) in both the brain and the eyes with respective values of 14.0-14.2 g/100 g crude protein (Glu) and 9.96-7.00 $\mathrm{g} / 100 \mathrm{~g}$ crude protein, cp (Asp). A look at Table 1 will show that AA of the brain was slightly less concentrated (on pair wise comparisons) than the corresponding $\mathrm{AA}$ in the eyes in eight or $47.1 \%$ parameters; of the nine essential AA determined, six of them or $66.7 \%$ were more concentrated in the eyes than the brain on pair wise comparisons. The most concentrated essential AA (EAA) in the samples was Arg

Table 1. Amino Acid Composition (g/100g Crude Protein) of Head Organs of Guinea Hen (Dry Weight)

\begin{tabular}{|c|c|c|c|c|c|}
\hline Amino Acid & Brain & Eyes & Mean & SD & $\mathrm{CV} \%$ \\
\hline $\mathrm{His}^{\mathrm{a}}$ & 3.03 & 2.50 & 2.77 & 0.37 & 13.6 \\
\hline $\operatorname{Arg}^{\mathrm{a}}$ & 7.10 & 4.75 & 5.93 & 1.66 & 28.0 \\
\hline Asp & 9.96 & 7.00 & 8.48 & 2.09 & 24.7 \\
\hline $\mathrm{Thr}^{\mathrm{a}}$ & 3.20 & 3.40 & 3.30 & 0.14 & 4.29 \\
\hline Glu & 14.0 & 14.2 & 14.1 & 0.14 & 1.00 \\
\hline Pro & 3.93 & 3.00 & 3.47 & 0.66 & 19.0 \\
\hline Gly & 3.26 & 3.60 & 3.43 & 0.24 & 7.01 \\
\hline Ala & 4.50 & 3.69 & 4.10 & 0.57 & 14.0 \\
\hline $\mathrm{Ile}^{\mathrm{a}}$ & 3.26 & 3.74 & 3.50 & 0.34 & 9.70 \\
\hline $\mathrm{Leu}^{\mathrm{a}}$ & 5.80 & 6.90 & 6.35 & 0.78 & 12.2 \\
\hline $\mathrm{Phe}^{\mathrm{a}}$ & 5.60 & 4.12 & 4.86 & 1.05 & 21.5 \\
\hline Tyr & 3.33 & 3.20 & 3.27 & 0.09 & 2.82 \\
\hline Try $^{a}$ & - & - & - & - & - \\
\hline Protein (fat free) & 60.7 & 64.4 & 62.6 & 2.62 & 4.18 \\
\hline
\end{tabular}

${ }^{\text {a }}$ Essential amino acid; - not determined; mean value is grand mean from the mean values of the amino acids. 
$(7.10 \mathrm{~g} / 100 \mathrm{~g} \mathrm{cp})$ in the brain and Leu $(6.90 \mathrm{~g} / 100 \mathrm{~g} \mathrm{cp})$ in the eyes. The coefficient of variation percent (CV \%) ranged between $1.00-42.0$ in the AA, with Glu having the least CV $\%$ and Cys the highest CV \%. From literature, the EAA with Cys and Tyr values had been given for the brain of cattle, pig and sheep[13]; for cattle brain, values in g/100gcp were: Leu (7.5), Ile (3.9), Lys (6.0), Met (2.1), Cys (1.8), Phe (5.0), Tyr (3.6), Thr (4.7), Val (4.9), His (2.5) and total (42.8); for pig brain: Leu (8.7), Ile (4.6), Lys (7.8), Met (2.0), Cys (-), Phe (5.1), Tyr (4.2), Thr (4.7), Val (5.7), His (2.7) and total (46.8); for sheep brain: Leu (7.8), Ile (4.0), Lys (6.4), Met (2.0), Cys (1.1), Phe (4.8), Tyr (3.7), Thr (4.5), Val (4.8), His (2.6) and total (42.8). With these literature values, our EAA results in the brain can be described as follows: Leu (5.80) was close to all the literature samples; Ile (3.26), Lys (5.04), Tyr (3.33), Thr (3.20) and Val (3.06) were very close to all the literature samples whereas Cys (1.20) was close to cattle brain result but better than the pig and sheep Cys values; Met (2.27), Phe (5.60) and His (3.03) were all better than the literature brain values respectively; the total of $35.8 \mathrm{~g} / 100 \mathrm{~g}$ was close to the literature values (Try was not determined in our samples). The total value for the eyes was $36.6 \mathrm{~g} / 100 \mathrm{~g}$ crude protein.

The FAO/WHO/UNU [10] standards for pre-school children $(2-5$ years) were $(\mathrm{g} / 100 \mathrm{~g}$ protein): Leu (6.6), Phe + Tyr (6.3), Thr (3.4), Try (1.1), Val (3.5), Ile (2.8), Lys (5.8), Met + Cys (2.5), His (1.9) and total (33.9 with His) and 32.0 (no His). Based on this information, the brain would provide enough or even more than enough of Phe + Tyr, Ile, Met + Cys, His and total EAA while the eyes would provide enough or even more of Leu, Phe + Tyr, Thr, Val, Ile, Met + Cys, His and total EAA. Tryptophan was not determined. Histidine is a semi-essential amino acid particularly useful for children growth. It is the precursor of histamine present in small quantities in cells. When allergens enter the tissues it is liberated in larger quantities and is responsible for nettle rash [14]. The value of Ile was $(3.26-3.74 \mathrm{~g} / 100 \mathrm{~g} \mathrm{cp})$ in the samples. It is an EAA for both old and young. Maple Syrup Urine Disease is an Inborn Error of metabolism in which brain damage and early death can be avoided by a diet low in Ile and two other EAA, Leu and Val. Both Ile, Leu and Val were high in the current report. Methionine is an EAA with value range of $2.27-2.50 \mathrm{~g} / 100 \mathrm{~g} \mathrm{cp}$ in this report or 3.47$3.15 \mathrm{~g} / 100 \mathrm{~g}$ cp with Cys. Methionine is needed for the synthesis of choline. Choline forms lecithin and other phospholipids in the body. When the diet is low in protein, for instance in alcoholism and kwashiorkor, insufficient choline may be formed; this may cause accumulation of fat in the liver [14]. Phenylalanine formed a value range of 5.60-4.12 $\mathrm{g} / 100 \mathrm{~g} \mathrm{cp}$ of the samples. It is the precursor of some hormones and the pigment melanin in hair, eyes and tanned skin. Phenylketonuria is the commonest inborn error of metabolism successfully treated by diet. The absence of an enzyme in the liver blocks the normal metabolism of phenylalanine and the brain is irreversibly damaged unless a diet low in phenylalanine is given in the first few weeks of life. Tyrosine value range was $3.33-3.20 \mathrm{~g} / 100 \mathrm{~g} \mathrm{cp}$. Tyrosine is the precursor of some hormones (like the thyroid hormones) and the brown pigment melanin formed in hair, eyes and tanned skin. It reduces the requirement of Phe. Permanent deficiency of the enzyme-hypertyrosinaemia, a rare inborn error of metabolism - can cause liver and kidney failure unless treated with a synthetic diet low in Phe and Tyr [14]. Valine an EAA is restricted in the treatment of Maple Syrup Urine Disease.

Table 2 presents parameters on the quality of the protein of the samples. The EAA ranged between $38.4-37.5 \mathrm{~g} / 100$ $\mathrm{g}$ cp with a variation of $1.68 \%$. These values were more than half the average of $56.6 \mathrm{~g} / 100 \mathrm{~g} \mathrm{cp}$ of the egg reference protein [8]. The total sulphur AA (TSAA) of the samples was $4.29 \mathrm{~g} / 100 \mathrm{~g} \mathrm{cp}$ (brain) and $4.38 \mathrm{~g} / 100 \mathrm{~g} \mathrm{cp}$ (eyes). The values of $4.29-4.38 \mathrm{~g} / 100 \mathrm{~g} \mathrm{cp}$ were close to the value of 5.8 $\mathrm{g} / 100 \mathrm{~g} \mathrm{cp}$ recommended for infants [10]. The aromatic AA (ArAA) range suggested for infant protein $(6.8-11.8 \mathrm{~g} / 100 \mathrm{~g}$ cp) [10] was very favourably comparable with the current report of 8.93-7.32 g/100 $\mathrm{g} \mathrm{cp}$ showing that the samples protein could be used to supplement sorghum flour [15]. The percentage ratio of EAA to the total AA (TAA) in the samples ranged between $47.5 \%$ and $52.2 \%$. These values were well above the $39 \%$ considered adequate for ideal protein food for infants, $26 \%$ for children and $11 \%$ for adults [10].

The percentage of EAA/TAA for the samples could be favourably compared with other animal protein sources: 46.2 $\%$ in Zonocerus variegatus [16], $43.7 \%$ in Macrotermes bellicosus [17] and $54.8 \%$ in Gymnarchus niloticus (Trunk fish) [18] whereas it is $50 \%$ for egg [19]. The TEAA in these results were close to the value of $44.4 \mathrm{~g} / 100 \mathrm{~g} \mathrm{cp}$ in soybean [20], melon and gourd oilseeds with respective values of $53.4 \mathrm{~g} / 100 \mathrm{~g} \mathrm{cp}$ and $53.6 \mathrm{~g} / 100 \mathrm{~g} \mathrm{cp} \mathrm{[21].} \mathrm{The} \mathrm{percentage} \mathrm{of}$ total neutral AA (TNAA) ranged from 51.6 - 52.8, indicating that these formed the bulk of the AA; total acidic AA (TAAA) ranged from $29.7-29.5$ which was far lower than $\%$ TNAA, while the percentage range in total basic AA (TBAA) was $18.8-17.7$ which made them the third largest group among the samples. The predicted protein efficiency ratio (P-PER) was 1.82 (brain) and 2.33 (eyes). These results were highly comparable to the following literature values: 2.27 (skin) and 1.93 (muscle) of turkey hen [22]; it is 2.22 (Clarias anguillaris), 1.92 (Oreochromis niloticus) and 1.89 (Cynoglossus senegalensis) [23] but lower than in the values from various parts of fresh water female crab: 3.4 (whole body), 3.1 (flesh), 2.6 (exoskeleton) [24]; fresh water male crab: 2.9 (whole body), 2.8 (flesh), 2.4 (exoskeleton) [25]; 4.06 (corn ogi) and reference casein with PER of 2.50 [26]; 2.56 (cattle brain), 3.04 (pig brain) and 2.68 (sheep brain) [13]. Other literature values were 1.21 (cowpea), 1.82 (pigeon pea) [27]; 1.62 (millet ogi) and 0.27 (sorghum ogi) [26]; greater than 0.00 (raw sorghum), 0.23 (steeped sorghum) and 0.29 (germinated sorghum) [15]. The Leu/Ile ratio was low in both samples $(1.78-1.84)$ with CV \% of 2.34 , hence no concentration antagonism might be experienced in the guinea fowl brain and eyes when used as protein source in food. The essential AA index (EAAI) ranged from 1.11 (brain) - 1.15 (eyes). EAAI is useful as a rapid tool to evaluate food formulations for protein quality, although it does not account for differences in protein quality due to various processing methods or certain chemical reactions [28]. The EAAI of defatted soybean is 1.26 [28]; this is close to the current results. In the results of the isoelectric points $(\mathrm{pI})$, there was a shift from 4.64 (brain) down to 4.32 (eyes). This type of shift was also observed in turkey meat: from 4.41 in skin to 5.01 in the muscle [22]. The calculation of $\mathrm{pI}$ from 
Table 2. EAA, non - EAA, Acidic, Neutral, Sulphur and Aromatic Acid Contents (g/100g Crude Protein) of Head Organs of Guinea Hen (Dry Weight)

\begin{tabular}{|c|c|c|c|c|c|}
\hline Amino Acid & Brain & Eyes & Mean & SD & CV\% \\
\hline Total amino acids (TAA) & 80.8 & 71.9 & 76.4 & 6.29 & 8.24 \\
\hline \multicolumn{6}{|l|}{ Total non-essential amino } \\
\hline acid (TN EAA) & 42.5 & 34.4 & 38.5 & 5.73 & 14.9 \\
\hline \multicolumn{6}{|l|}{ Total EAA } \\
\hline$\%$ TNEAA & 52.5 & 47.8 & 50.2 & 3,32 & 6.63 \\
\hline \multicolumn{6}{|l|}{$\%$ Total EAA } \\
\hline With His & 47.5 & 52.2 & 49.9 & 3.32 & 6.67 \\
\hline No His & 43.7 & 48.7 & 46.2 & 3.54 & 7.65 \\
\hline$\%$ TNAA & 51.6 & 52.8 & 52.2 & 0.85 & 1.63 \\
\hline \multicolumn{6}{|l|}{ Total acidic amino } \\
\hline acid (TAAA) & 24.0 & 21.2 & 22.6 & 1.98 & 8.76 \\
\hline$\%$ TAAA & 29.7 & 29.5 & 29.6 & 0.14 & 0.48 \\
\hline \multicolumn{6}{|l|}{ Total basic amino } \\
\hline acid (TBAA) & 15.2 & 12.8 & 14.0 & 1.70 & 12.1 \\
\hline$\%$ TBAA & 18.8 & 17.7 & 18.3 & 0.78 & 4.26 \\
\hline \multicolumn{6}{|l|}{ Total sulphur amino } \\
\hline acid (TSAA) & 3.47 & 3.15 & 3.31 & 0.23 & 6.84 \\
\hline $\mathrm{P}$ - PER & 1.82 & 2.33 & 2.08 & 0.36 & 17.4 \\
\hline Leu/Ile ratio & 1.78 & 1.84 & 1.81 & 0.04 & 2.34 \\
\hline Leu-Ile (difference) & 2.54 & 3.16 & 2.85 & 0.44 & 15.4 \\
\hline$\%$ Leu-Ile (difference) & 48.1 & 45.8 & 47.0 & 1.63 & 3.46 \\
\hline EAAI & 1.11 & 1.15 & 1.13 & 0.03 & 2.50 \\
\hline Isoelectric point (pI) & 4.64 & 4.32 & 4.48 & 0.23 & 5.05 \\
\hline
\end{tabular}

amino acids would assist in the production of the protein isolate of an organic product.

Most animal proteins are low in Cys, for examples: $36.3 \%$ in M. bellicosus [17], $25.6 \%$ in Z. variegatus [16]; $35.5 \%$ in Archachatina marginata; $38.8 \%$ in Archatina archatina and $21.0 \%$ in Limicolaria sp.; respectively [29]; $27.3 \%-32.8 \%$ in female fresh water crab body parts [24]; $23.8 \%-30.1 \%$ in three different Nigeria fishes [23]; 13.3 $\%-15.9 \%$ in male fresh water crab body parts [25]; $26.0 \%$ - $26.5 \%$ in turkey hen meat [22] in their (Cys/TSAA) \% values. The present results corroborated these literature obser- vations with values of 34.6 down to $20.6 \%$. In contrast, many vegetable proteins contain substantially more Cys than Met, examples (Cys/TSAA) \%: $62.9 \%$ in coconut endosperm [30]; and in Anacardium occidentale it is $50.5 \%$ [31]; and 58.9-72.0 in sorghum (raw, steeped, germinated) [15]. Thus, for animal protein diets or mixed diets containing animal protein, Cys is unlikely to contribute up to $50 \%$ of the TSAA [32]. The percentage of Cys in TSAA had been set at $50 \%$ in rat, chick and pig diets [32]. Cys can spare with Met in improving protein quality and has positive effects on mineral absorption, particularly zinc $[33,34]$. 
Table 3 shows the AA scores (AAS) of the samples based on whole hen's egg profile [8]. The scores had values greater than 1.0 in His, Arg, Glu, Pro, Gly and Phe in the brain; they were His, Glu and Gly in the eyes. Histidine had the highest score (1.26) in brain whereas Gly (1.20) had it in the eyes; the least score was Ser (0.29) in the brain and it was the Cys (0.36) in the eyes. The guinea fowl head organs (brain and eyes) generally showed good comparisons with the AA profile of the whole hen's egg. The CV \% between AA levels of brain and eyes ranged between $0.60-42.6$. Table 4 shows the essential AA scores (EAAS) based on the provisional amino acid scoring pattern [9]. EAAS greater than 1.0 in the brain was Phe + Tyr whereas it was Lys and Phe + Tyr in the eyes. The limiting AA (LAA) in the brain was Val (0.61) whereas it was also Val (0.82) in the eyes. Although this would have been described as the LAA, however, the EAA most often acting in a limiting capacity are methione (and cysteine), lysine, threonine and tryptophan [10]. Since Try was not determined, Thr would be limiting in brain (0.80) and the eyes (0.85). To make corrections for the LAA in the samples if they serve as sole sources of protein food therefore, it would be $100 / 80.0 \times$ protein of brain and $100 / 85.0 \times$ protein of eyes; or $1.25 \times$ protein of brain and $1.18 \times$ protein of eyes. The highest EAAS in the brain was Phe + Tyr (1.49) and also Phe + Tyr (1.22) in the eyes. The Table 5 shows the EAAS based on suggested requirement of the EAA of a preschool child [10]. It is interesting to note that Thr, Val, Leu and Lys had EAAS less than 1.0 in brain whereas only Lys had EAAS less than 1.0 in the eyes. Unlike in Table 4, His had the highest score (1.59) in the brain whereas Ile had the highest score (1.34) in the eyes. The LAA in brain was Lys (0.869) and also Lys in the eyes (0.95) with respective corrections of $100 / 86.9$ (1.15) x protein of brain and 100/95.0 (1.05) x protein of eyes.

Table 3. Amino Acid Scores of the Guinea Hen Head Organs Based on Whole Hen's Amino Acid Profile

\begin{tabular}{|c|c|c|c|c|c|}
\hline Amino Acid & Brain & Eyes & Mean & SD & CV\% \\
\hline Lys & 0.81 & 0.89 & 0.85 & 0.06 & 6.66 \\
\hline His & 1.26 & 1.04 & 1.15 & 0.16 & 13.5 \\
\hline Arg & 1.16 & 0.78 & 0.97 & 0.27 & 27.7 \\
\hline Asp & 0.93 & 0.65 & 0.79 & 0.20 & 25.1 \\
\hline Thr & 0.63 & 0.67 & 0.65 & 0.03 & 4.35 \\
\hline Glu & 1.17 & 1.18 & 1.18 & 0.01 & 0.60 \\
\hline Pro & 1.03 & 0.79 & 0.91 & 0.17 & 18.6 \\
\hline Gly & 1.09 & 1.20 & 1.15 & 0.08 & 6.79 \\
\hline Ala & 0.83 & 0.68 & 0.76 & 0.11 & 14.0 \\
\hline Ile & 0.58 & 0.67 & 0.63 & 0.06 & 10.2 \\
\hline Leu & 0.70 & 0.83 & 0.77 & 0.09 & 12.0 \\
\hline Tyr & 0.83 & 0.80 & 0.82 & 0.02 & 2.60 \\
\hline Phe & 1.10 & 0.81 & 0.96 & 0.21 & 21.5 \\
\hline
\end{tabular}

Table 4. Amino Acid Scores of the Guinea Hen Head Organs Based on the Provisional Essential Amino Acid Scoring Pattern

\begin{tabular}{|c|c|c|c|c|c|}
\hline Amino Acid & Brain & Eyes & Mean & SD & CV\% \\
\hline Lys & 0.92 & 1.00 & 0.96 & 0.06 & 5.89 \\
\hline Thr & 0.80 & 0.85 & 0.83 & 0.04 & 4.29 \\
\hline Met + Cys & 0.99 & 0.90 & 0.95 & 0.06 & 6.73 \\
\hline Val & 0.61 & 0.82 & 0.72 & 0.15 & 20.8 \\
\hline Ile & 0.82 & 0.94 & 0.88 & 0.08 & 9.64 \\
\hline Leu & 0.83 & 0.99 & 0.91 & 0.11 & 12.4 \\
\hline Phe + Tyr & 1.49 & 1.22 & 1.36 & 0.19 & 14.1 \\
\hline Try & - & - & na & na & na \\
\hline Total & 0.94 & 0.97 & 0.96 & 0.02 & 2.22 \\
\hline
\end{tabular}

- not determined; na = not available. 
The following values would show the position of the quality of the guinea hen brain and eyes protein: the EAA requirements across board are (values with His) (g/100g protein): infant (46.0), pre-school (2 - 5 years) (33.9), school child (10 - 12 years) (24.1) and adult (12.7) and without His: infant (43.4), pre-school (32.0), school child (22.2) and adult (11.1) [10]; from the present results based on these standards, we have: $35.8 \mathrm{~g}$ protein (with His) and 32.8 (no His) in brain; $36.6 \mathrm{~g}$ protein (with His) and 34.1 (no His) in eyes. While the current results would satisfy a high percentage of infant needs, they will satisfy the requirements of pre-school children and above.

Table 6 gave a brief summary of the AA profile in the two samples. Column under factor B means showed that the values there were very close with a range of $38.0-38.5$.
However, Table 7 depicts the summary of the statistical analysis of results in Tables $\mathbf{1 , 2}$ (pI only) $\mathbf{3}, \mathbf{4}$ and $\mathbf{5}$. The simple linear correlation coefficient $\left(\mathrm{r}_{\mathrm{xy}}\right)$ values showed high positive and significant results from Tables $\mathbf{1 , 2}$ (pI only), $\mathbf{3}$, $\mathbf{4}$ and $\mathbf{5}$ but $r_{x y}$ values being highest in $\mathbf{1}$ and $\mathbf{4}$ at $r_{0.05}$ and $\mathrm{n}-$ 2 degrees of freedom. The regression coefficient $\left(R_{x y}\right)$ showed that for every unit increase in the brain AA parameter, the increase was 0.35 (Table 1), 5.87 (Table 2, pI only), 0.25 (Table 3), 0.56 (Table 4) and 0.74 (Table 5).

The coefficient of alienation $\left(\mathrm{C}_{\mathrm{A}}\right)$ was low in Table $\mathbf{1}$ $(0.36$ or $36 \%)$, Table $2(0.46$ or $46 \%)$ and Table $4(0.42$ or $42 \%)$ but high in Table $3(0.66$ or $66 \%)$ and $5(0.69$ or 69 $\%$ ). The index of forecasting efficiency (IFE) was high in Table $1(0.64$ or $64 \%)$, Table $2(0.54$ or $54 \%)$ and Table 4 $(0.58$ or $58 \%)$ while others were low at between $31-34 \%$

Table 5. Amino Acid Scores of the Guinea Hen Head Organs Based on the Suggested Requirement of the essential Amino Acid of a Preschool Child

\begin{tabular}{|c|c|c|c|c|c|}
\hline Amino Acid & Brain & Eyes & Mean & SD & CV\% \\
\hline Lys & 0.869 & 0.95 & 0.91 & 0.06 & 6.30 \\
\hline His & 1.59 & 1.32 & 1.46 & 0.19 & 13.1 \\
\hline Thr & 0.94 & 1.00 & 0.97 & 0.04 & 4.37 \\
\hline Val & 0.874 & 1.17 & 1.02 & 0.21 & 20.5 \\
\hline Met + Cys & 1.39 & 1.26 & 1.33 & 0.09 & 6.94 \\
\hline Ile & 1.16 & 1.34 & 1.25 & 0.13 & 10.2 \\
\hline Leu & 0.88 & 1.05 & 0.97 & 0.12 & 12.5 \\
\hline $\mathrm{Phe}+\mathrm{Tyr}$ & 1.42 & 1.16 & 1.29 & 0.18 & 14.3 \\
\hline Try & - & - & na & na & na \\
\hline Total & 1.09 & 1.12 & 1.11 & 0.02 & 1.92 \\
\hline
\end{tabular}

— not determined; na $=$ not available.

Table 6. Summary of the Amino Acid Profiles into Factors A and B

\begin{tabular}{|l|l|l|l|}
\hline & \multicolumn{1}{|c|}{ Samples (Factor A) } & Fyes & Factor B means \\
\hline Amino acid composition (Factor B) & Brain & & \\
\hline Total essential amino acid & & 37.5 & 38.0 \\
\hline Total non-essential amino acid & 38.4 & 34.4 & 38.5 \\
\hline Factor A means & 42.5 & 36.0 & 38.3 \\
\hline
\end{tabular}

Table 7. Summary of the Statistical Analysis of the Data in Tables 1, 2, 3, 4 and 5

\begin{tabular}{|c|c|c|c|c|c|c|}
\hline From Table & $\mathbf{r}_{\mathrm{xy}}$ & $\mathbf{r}_{\mathrm{xy}}^{2}$ & $\mathbf{R}_{\mathrm{xy}}$ & CA & IFE & Remark \\
\hline 1 & 0.9323 & 0.87 & 0.35 & 0.36 & $64 \%$ & $*$ \\
\hline 2 (pI only) & 0.8911 & 0.79 & 5.87 & 0.46 & $54 \%$ & $*$ \\
\hline 3 & 0.7527 & 0.57 & 0.25 & 0.66 & $34 \%$ & $*$ \\
\hline 4 & 0.9078 & 0.82 & 0.56 & 0.42 & $58 \%$ & $*$ \\
\hline 5 & 0.7225 & 0.52 & 0.74 & 0.69 & $31 \%$ & $*$ \\
\hline
\end{tabular}

$*$, result significant at $\mathrm{r}_{0.05}$ at $\mathrm{n}-2$ degrees of freedom. 
(Tables 5 and 3). Low IFE versus high $\mathrm{C}_{\mathrm{A}}$ makes prediction of relationship difficult. The $\mathrm{C}_{\mathrm{A}}$ produces an index of lack of relationship while the IFE gives the reduction in errors of prediction or relationship. The $\mathrm{C}_{\mathrm{A}}$ and IFE values showed that a good relationship existed between the brain and eyes AA in Numida meleagris particularly with the results in Tables $\mathbf{1}, \mathbf{2}$ and $\mathbf{4}$. The pattern of $r_{x y}$ results from Tables $\mathbf{1}$ and $\mathbf{2}$ were similar to those obtained for the amino acid profiles of the shell and flesh of Penaeus notabilis [35].

\section{CONCLUSIONS}

This study has presented the amino acid data of the head organs (brain and eyes) of guinea fowl (Numida meleagris) hen. It was found that the samples were good sources of high quality protein of almost adequate or more than adequate of essential amino acids, low Leu/Ile ratio and high protein efficiency ratio values thereby providing a probable premium quality meat. The analysis of the eyes would also improve the information in the food composition Tables.

\section{REFERENCES}

[1] NRC (National Research Council). Microlivestock: little - known small animals with a promising economic future. Washington DC: National Academy Press, 1991.

[2] Pearson D. Chemical Analysis of Foods. $7^{\text {th }}$ ed. London: Churchill Livingstone, 1976.

[3] Association of Official Analytical Chemists. Official Methods of Analysis. $18^{\text {th }}$ ed. Washington DC: 2005.

[4] Spackman DH, Stein WH, Moore S. Chromatography of amino acids on sulphonated polystyrene resins. An improved system. Anal Chem 1958; 30: 1190-205.

[5] Olaofe O, Akintayo ET. Prediction of isoelectric points of legume oilseed proteins from their amino acid composition. J Technosci 2000; 4: 49-53.

[6] Finar IL. Organic Chemistry. $5^{\text {th }}$ ed. London: ELBS and Longman Group, 1975; Vol. 2.

[7] Alsmeyer RH, Cunningham AE, Happich ML. Equations to predict PER from amino acid analysis. Food Technol 1974; 28: 34-38.

[8] Paul AA, Southgate DAT, Russel J. First Supplement to McCance and Widdowsons's the Composition of Foods. London: Her Majesty's Stationery Office, 1980.

[9] FAO/WHO. Energy and Protein Requirements. Technical report series, No. 522, Geneva, Switzerland, 1973.

[10] FAO/WHO/UNU Energy and Protein Requirements. Technical report series, No. 724, Geneva, Switzerland, 1985.

[11] Steinke FH, Prescher EE, Hopkins DT. Nutritional evaluation (PER) of isolated soybean protein and combinations of food proteins. J Food Sci 1980; 45: 323-7.

[12] Oloyo RA. Fundamentals of Research Methodology for Social and Applied Sciences. Ilaro, Nigeria: ROA Educational Press, 2001.

[13] Fornias OV. Edible by-products of slaughter animals. FAO animal production and health paper 123. Rome: FAO, 1996.

[14] Bingham S. Dictionary of Nutrition. London: Barrie and Jenkins, 1977.
[15] Adeyeye EI. The intercorrelation of the amino acid quality between raw, steeped and germinated guinea corn (Sorghum bicolor) grains. Bull Chem Soc Ethiopia 2008; 22(1): 11-7.

[16] Adeyeye EI. Amino acid composition of variegated grasshopper, Zonocerus variegatus. Trop Sci 2005; 45(4): 141-3.

[17] Adeyeye EI. The composition of the winged termites, Macrotermes bellicosus. J Chem Soc Nig 2005; 30(2): 145-9.

[18] Adeyeye EI, Adamu AS. Chemical composition of food properties of Gymnarchus niloticus (Trunk fish). Biosci Biotechnol Res Asia 2005; 3(2): 265-72.

[19] Protein Quality Evaluation. Report of Joint FAO/WHO consultation, Bethesda MD, 4-8 December, 1989. Rome: FAO/WHO, 1990.

[20] Kuri YE, Sundar RK, Kahuwi C, Jones GP, Rivett DE. Chemical composition of Monerdica charantis L. fruits. J Agric Food Chem 1991; 39: 1702-3.

[21] Olaofe O, Adeyemi FO, Adediran GO. Amino acid and mineral compositions and functional properties of some oilseeds. J Agric Food Chem 1994; 42(4): 879-81.

[22] Adeyeye EI, Ayejuyo OO. Proximate, amino acids and mineral composition of turkey-hen muscle and skin. Orient J Chem 2007 23(3): 879-86.

[23] Adeyeye EI. Amino acid composition of three species of Nigerian fish: Clarias anguillaris, Oreochromis niloticus and Cynoglossusn senegalensis. Food Chem 2009; 113: 43-6.

[24] Adeyeye EI. Amino acid composition of the whole body, flesh and exoskeleton of female common West African fresh water crab Sudananautus africanus africanus. Int J Food Sci Nutr 2008; 59(7-8): 699-705.

[25] Adeyeye EI, Kenni AM. The relationship in the amino acid of the whole body, flesh and exoskeleton of male common West African fresh water crab Sudananautus africanus africanus. Pak J Nutr 2008; 7(6): 748-52.

[26] Oyarekua MA, Eleyinmi AF. Comparative evaluation of the nutritional quality of corn, sorghum and millet $o g i$ prepared by modified traditional technique. Food Agric Environ 2004; 2: 94-99.

[27] Salunkhe DK, Kadam SS. Handbook of World Food Legumes Nutritional Chemistry, Processing Technology and Utilization. Florida, USA: Boca Raton, CRC Press, 1989.

[28] Nielsen SS. Introduction to the Chemical Analysis of Foods. New Delhi: CBS Publishers and Distributors, 2002.

[29] Adeyeye EI, Afolabi EO. Amino acid composition of three different types of land snails consumed in Nigeria. Food Chem 2004; 85: 535-9.

[30] Adeyeye EI. The chemical composition of liquid and solid endosperm of ripe coconut. Orient J Chem 2004; 20(3): 471-6.

[31] Adeyeye EI, Asaolu SS, Aluko AO. Amino acid composition of two masticatory nuts (Cola acuminata and Garcinia kola) and a snack nut (Anacardium occidentale). Int J Food Sci Nutr 2007; 58(4): 241-9.

[32] Protein Quality Evaluation. Report of joint FAO/WHO expert consultation. FAO Food Nutrition paper No. 51. Rome: FAO/WHO, 1991

[33] Mendoza C. Effect of genetically modified low phytic acid plants on mineral absorption. Int J Food Sci Technol 2002; 37: 759-67.

[34] Sandstrom B, Almgren A, Kivisto B, Cederblad A. Effect of protein and protein source on zinc absorption in humans. J Nutr 1989; 119: 48-53.

[35] Adeyeye EI, Adubiaro HO, Awodola OJ. Chemical composition and functional properties of shell and flesh of Penaeus notabilis. Pak J Nutr 2008; 7(6): 741-7.

(C) Adeyeye and Aremu; Licensee Bentham Open.

This is an open access article licensed under the terms of the Creative Commons Attribution Non-Commercial License (http://creativecommons.org/licenses/by-nc/3.0/) which permits unrestricted, non-commercial use, distribution and reproduction in any medium, provided the work is properly cited. 